\title{
Moderating role of Emotional Intelligence on the influencing role of family on student employability
}

\author{
${ }^{1}$ V. Mohana Sundari, ${ }^{2}$ Challapalli Praseeda \\ ${ }^{1}$ Assistant Professor, Department of Management Studies, SRM IST-Vadapalani, Chennai \\ ${ }^{2}$ Professor, Department of Management Studies, SRM IST-Vadapalani, Chennai
}

\begin{abstract}
Employability, refers to a wider set of skills and attributes which will transform graduates to achieve success throughout their career life. Improving the employability abilities is considered as the significant goal for any student. Emotional Intelligence refers to the extent of knowledge which expresses one to feel and act accordingly. This study focuses on identifying the impact of family dimensions on students' employability and also on understanding the moderating role of emotional intelligence on family dimension and employability, as research shows that employability has an undeniable connect with Emotional Intelligence. Descriptive research was used for the study and the data was collected with the help of structured questionnaire. The results of the study show that family dimensions have a direct impact on employability whereas the moderating role of Emotional Intelligence was negative with reference to influence of family dimensions' family dimensions.
\end{abstract}

Keywords: Employability, Emotional Intelligence, family dimension, moderating role

\section{INTRODUCTION}

Employability is possessing a set of competencies and or skill sets by graduate students which make them secure desirable employments, either in the formal sector or in self-employment ventures. In addition, employability is the result of the interaction of different abilities skills and competencies, knowledge and prior experience acquired through higher education and continuous learning [1]. Harvey (2001) makes an attempt to define employability and identifies two major issues that emerge out of the dichotomy in the thought process of whether to consider employability a graduate outcome or institutional outcome. Despite the existence of certain methodological issues and the lack of "common conceptual language of employability it has been identified by Harvey (2001) that "employability is a process to be understood rather than output to be measured". The present study also makes an attempt to examine the impact of family related dimensions on the process of employability. An attempt is made to understand the existence of the influence of emotional intelligence as a moderator.

Employment has always been a defining factor in the lifestyle and economic status of an individual and has an undeniable impact on family and its prosperity, and the purpose of higher education is often considered as a means of developing the skills and capabilities necessary to lead to gainful employment. Thus, education and employability are inextricably entwined together yet are not completely exclusive in themselves. Employability of students is dependent 
on multiple and different aspects that are falling under category of attitude, skills and knowledge of students. Employability is not only relying on abilities of individuals to meet requirements of job but also on factors as compared to others in the job structure with desired competencies [5] and it is also determined by the family expectations and its characteristics. Family as a factor has been acknowledged but not fully explored. The present study makes an attempt to understand the impact of family on employability especially with reference to students on the threshold of embarking upon a career.

\section{REVIEW OF LITERATURE EMPLOYABILITY}

Employability is viewed differently by individuals as a combination of skill sets and personal characteristics which make students to get best employment and be success in their jobs, leading to benefits to community, society, nation and self [6]. Employability is capacity of individuals to be self-sufficient in acquiring job and to use their potentiality for jobs and sustainability of their professional life [7]. Furthermore, employability is the capacity of students to get a job that satisfies their ambitions in profession and personal life. Employability refers to the ability of the applicant to showcase features and characters which employers expect will be essential for carrying out jobs efficiently in their organizations [8].

The emerging multinational and digital environment has ushered a drastic transformation in employment structure [9,10], and career opportunities are seen horizontally projecting an upward trend. The concept of job is fast becoming flexible and is not a concrete and fixed group of activities and required competencies are not fixed for a particular job over the period of years and are changing over time horizons [11]. This suggests the emerging flexible nature of jobs and the need for the employment seeker to incorporate flexibility and multi- skills proficiency into their skills of employability. Individuals are thus needed to change themselves to fit with changing job atmospheres, requirements of industrial organizations. As an outcome, skills for employability are highly essential to enable the students to adapt with the existing and dynamic transformation in the job market and industrial situation [12]. These skill sets will help them to identify various job opportunities with the objective of improving their prospects for employability and coordinate them in to their personal life aspirations.

Wickramasinghae and Perera (2010) made an attempt to explore the employability skills that are preferred by graduates, university faculty and the employers with specific relations to computer science field of Sri Lanka. One of their major findings was related to the graduate responses regarding the skills they possessed and the ideal skills that they should possess. All the groups of the study considered skills of solving problems, managing in teams and inherent self- confidence as essential to enhance employability suggesting a need to develop "Employability Assets". These include fundamental assets like personal features comprising of integrity, honesty and dependability and fundamental skill sets, intermediate assets namely job oriented specific skills, key and generic skills namely problem solving and communication skills and high level assets namely commercial awareness and team work skills that are essential for performance of organizations. The study also identified other factors like 
the ability of an individual to present himself or herself, during interview and group discussion, the ability to be able to deploy these skills at the right moment, and the impact of contextual factors like personal situations, social, cultural and economic conditions of which family related dimension can be included [13].

\section{EDUCATIONAL INSTITUTIONS AND EMPLOYABILITY}

Educational institutions are involved in development of human capital that contribute significantly to progress of nation by developing required competencies and knowledge in students that make them highly employable in various business organizations [14-16]. Competent students are getting better jobs and higher earnings in business organizations [17]. In other words, educational institutions like universities perform two main functions of providing the nation with the competent man power and are preparing the best students to develop the country and providing instructional support to research activities in all formats of knowledge and competencies [18]. Conventional graduate oriented job market is highly competitive in nature and graduates have variety of job options compared to earlier periods because of advancement of technologies and growing nature of economy [19].

Harvey and Morey (2002) state that employability is an engagement of individuals with job opportunities which reflects their abilities and prior experience in relation to specific jobs. There is a need to develop a model of employability that connects different components like employment opportunities, employers, assisting activities and the other parties involved in the process of developing employable skills. Such a model will be helpful in designating and defining the role of each of these components and also will clarify the inter relationships between components. The result of such a model will be creation of a multi-dimensional picture of employability, its precedents and antecedents and their manifestations. These activities are highly supported by educational institutions and training organizations through by means of development of skills, guidance and counselling and theoretical and practical experiences by industry oriented curriculum and trainings[ibid].

\section{FAMILY DIMENSIONS AND EMPLOYABILITY}

Perceived family support and parent personal involvement is considered as part of family dimension. Parental support has also been considered an important influence in creation of identities during the educational period of a student [20]. Research has also identified relationship between parental education and academic achievement of the student whereby a parent with higher educational qualification is considered to have better impact on the educational success of the student due to the "cultural capital "provided by the parent due to the advantage of education [21]. In this context, the present study raises a research question with regard to the role of parental influence on student employability.

Rice et al (1997) states that parental attachment is considered as one of the major factors that leads to emotional balance among children and has an undeniable impact on their social skills [22]. Fincham (2004) states that the evaluation of kids' ttributions have been done 
in parent-kid connections and analysis of their relationship have showed that the behaviour of children is always influenced by the parent. The parental expectations therefore have a great effect on student actions [23]. It is inferred that parents' direction help students to mould themselves to get better placement. The process of family support and other variables of the family were hence seen to be "career construct" [24]. Yamamoto (2010) states that there are high expectations from parent's side is transferred to the children and sometimes might create pressure on children to perform as per parental expectations. High expectations on the positive side might additionally produce a self-fulfilling insight, boosting student's own expectations regarding their ability and so motivating them to try and do well [25]. Metheny and McWhirtner (2013) state that two components namely status of the family and the support given by them helps the student to achieve "social cognitive career development outcomes" [26]. Parental expectations along with direction works together to motivate the students to increase their effort and search for better employment.

"Parental involvement is a form of investment made by parents for the future benefit of their children" (Smits and Hosgor, 2006 as quoted in Vellymalay 2011)[27]. Parental expectations have been designated has highly important cultural factors affecting the academic achievement of adolescents in Indian context ( Sasikala and Karunanidhi 2011)[28] Indian family system is considered as highly characterized by patriarchy, join family system where mother is the nurturer and father is the decision maker. Academic achievement of the children is considered as a matter of pride by the family. Father was considered to have influence on the education choice which would ultimately impact the career choice of the children (Sriram \& Sandhu 2012) [29]. Most Indian parent are also consider that their parental expectation is essential to "infuse their children with confidence, self-esteem, and personal standards of merit and value" but fail to realize that often it is these expectations that are unrealistic and unattainable and are counterproductive (Sasikala and Karunanidhi 2011)[ibid].

A number of studies focusing on the parental involvement have shown that studies have shown that the degree of parental involvement is directly associated with parental social class showing a positive relationship between the parents social class and their involvement in their child's education (Vellymalay 2011)[30]. This suggests that parents belonging to a good scoio economic profile have a positive influence on their wards educational decisions thereby making income and important demographic factor that might influence the educational decisions of the students. The study made by Thergaonkar (2007)[31] identified that parental expectations and anxiety adversely affect the children and highly educated parents have a higher impact on the children and their education (Sriram and Sandhu 2011)[ibid].

\section{EMOTIONAL INTELLIGENCE AND EMPLOYABILITY}

Emotional intelligence is the capability of individual to understand, assess and make emotions that help to improve their knowledge and thinking and regulation of their feelings in order to improve their progress in life [32]. Emotional intelligence is an integral element of cognitive skills of individuals [33]. Individuals with higher degree of emotional intelligence have the ability to manage their own emotions and those of others effectively and generate better relation with other individuals. Emotional intelligence is an inseparable component of 
employability and competencies, personal attributes and talents are also associated with employability in coupled with emotional intelligence. Here, a research question maybe raised with regard to the possibility of EI playing a moderating role between the employability and its antecedents.

Individual having high degree of emotional intelligence are self-motivated and also motivate other individuals for the objective of achieving high in their jobs and life. These people are comparatively positive in their approach and enjoy healthy personal relations at work due to which they are able to scale heights in their professional lives. Thus, emotional intelligence is the significant predictor of employability [34]. Individual principles, motivational levels, personal values, personalities and motives are the factors that largely influence employability of individuals $[35,36]$. And it is also has a positive impact on the mental health of individuals and providing better employability of individuals [37]. Emotional intelligence and employability are strongly integrated and it improves employability of individuals with great sense of confidence [38]. In addition, emotional intelligence is to be considered for substantial results relevant to employability [39]. In the academic scenario, by implementing emotional intelligence theory and exercises, faculty members will assist their graduate and post graduate students for their development competencies and employability. Emotional intelligence of students can be improved by their family, educational institutions and community [40].

\section{EMOTIONAL INTELLIGENCE, STUDENTS AND EMPLOYABILITY}

Many studies have proved that there is direct relationship between Emotional Intelligence and academic performance of students. Neelima (2011) found that there was a significant relation between emotional intelligence, mental strength and self-confidence and academic performance of university students [41]. Bai (2011) concluded that arts and science and commerce pre university students were having significant difference in their emotional intelligence and it had significant impact on academic achievement, anxiety and mental stability [42]. Zarafshan and Ardeshiri (2012) showed that emotional intelligence was significantly and positively impacting English learning strategies, proficiency of speaking English and academic success [44]. On the other hand Shahmohamadi and Hasanzadeh (2011) revealed lack of significant impact of emotional intelligence and achievement in language learning of undergraduate students [43].

Puffer (2011) found that emotional intelligence was positively related to selfefficacy and problem solving skills of college students and also had a positive impact on employability of college students [45]. EI helps students to clear the selection test in the interview process through enhanced commitment and problem solving skills. Rateau, et. al., (2011) revealed that employability of under graduate students was significantly impacted by their emotional intelligence and it was also positively related with their job selection [47]. Ahangar (2012) showed that emotional intelligence had increased employability skill of under graduate students and it was positively related with their employability [48]. EI also directly improves the employability skills of the students and trigger them to make the better career 
option[49]. Difabio and Buci, (2013) found that employability of college students was positively and significantly related with their emotional intelligence as the students with higher degree of emotional intelligence would have better employability and career management [50]. All the studies quoted here is to establish the strong connection between positive relationship between EI and employability of the students. The study of Rupande (2015) revealed that emotional intelligence had positive impact on learning of students and it was also positively and significantly related with their self-adjustment and solving problems and was negatively correlated with their stress and strain [51]. The above studies indicate the undeniable impact of emotional intelligence on student's employability. The present study tests not the direct relationship but the role of EI in relation to parental dimensions and employability.

\section{OBJECTIVES}

The objectives are framed based on the literature review on the topic and they are

1. To study the influence of parental personal involvement over employability.

2. To study the influence of perceived family support over employability.

3. To analyze the relationship between family dimensions and employability using emotional intelligence as a moderator.

\section{PROPOSED MODEL FOR PRESENT STUDY}

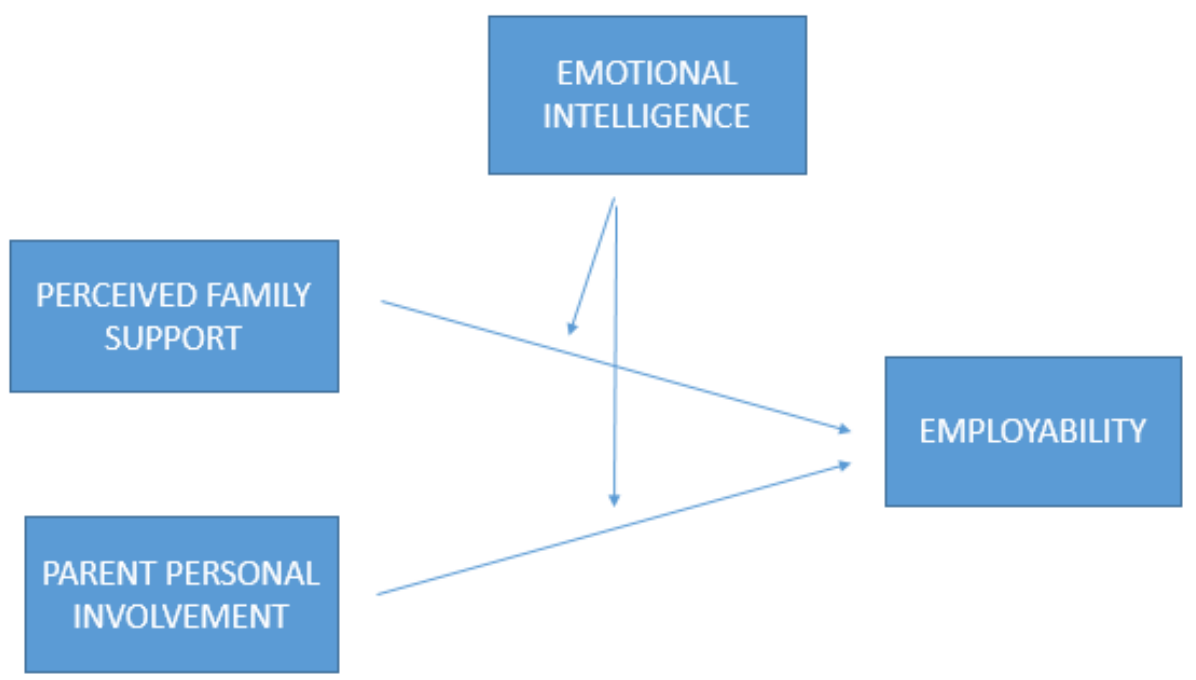

\section{METHODOLOGY:}

Research in social sciences is primarily a collaborative activity, which objectively examines a social reality [52]. It is a combination of qualitative and quantitative research which is being referred to as triangulation [53]. The current research found a few research gaps related to employability and emotional intelligence and built a model to address these gaps. Since this study aims to describe the phenomena of relationship between family dimensions leading to student employability and the inherent impact of emotional intelligence, this study can be termed as a descriptive study. The instrument used for the study is a combination of 3pre tested 
and published instruments gained with permissions from respective authors. The UCLan Career EDGE Peter Sewell and Lorraine Dacre Pool, 2010 [ 54] was used without any modifications as per the directions of the author. The TEIQue-SF [55] was used for measuring Emotional Intelligence and dimensions of family expectations using 7 items. A sample of 445 second year Management students were selected by employing simple random sampling technique. By collecting an exhaustive list of a wider population and then randomly choosing a certain number of individuals to compose the sample, researchers produce a simple random sample. With a simple random sample, there is an equal probability for any member of the wider population to be chosen. From a total population of 19250 final year management students, a random sample of 500 students was drawn. From the sample of 500, 445 usable questionnaires were obtained.

\section{DATA ANALYSIS}

The objective of the present study was to study the moderating role of Emotional Intelligence on employability. Both the qualitative and the quantitative methods are used in this study. A range of statistical methods, such as reliability testing, cross tabulation, regression analysis, discriminant analysis, hypothesis testing and Process Macro for meaningful derivation and conclusion is used.

Reliability test

\begin{tabular}{|l|c|c|}
\hline \multicolumn{1}{|c|}{ Dimension } & Total Sub Items & Cronbach's Alpha \\
\hline Family Dimensions & 07 & 0.916 \\
\hline Emotional Intelligence & 33 & 0.954 \\
\hline Employability & 25 & 0.959 \\
\hline Overall & 84 & 0.980 \\
\hline
\end{tabular}

The Cronbach's Alpha value is used to check the reliability values of tested questionnaire dimensions. The tested study dimensions are $>0.700$, which reflects good internal consistency. The overall Cronbach's Alpha value is 0.980 . This value is more than 0.700 . This indicates a very strong internal consistency among the variables.

Overall weighted average Mean and SD of variables

\begin{tabular}{|l|c|c|}
\hline \multicolumn{1}{|c|}{ Factors } & Mean & SD \\
\hline Employability & 5.21 & 1.64 \\
\hline Family dimensions & 5.42 & 1.72 \\
\hline Emotional Intelligence & 5.79 & 3.29 \\
\hline
\end{tabular}

The dependent variable Employability had 16 items, the independent variable family dimensions had 7 items and the moderating variable Emotional Intelligence had 33 items respectively for which mean and standard deviation has been done. All the items have the mean value more than 3.5 and this shows that the respondents have positive perceptions on the listed items and agreed with the given statements. Thus the study presents the average mean values of the Independent variable the impact family dimensions are favourable, the dependent variable also shows that most of the respondents are positive towards their responses and 
moderating variable wherein it is seen that most of the responses are highly positive indicating a positive emotional quotient in the respondents.

Parents occupation of the respondents

\begin{tabular}{|c|c|c|c|}
\hline Response types & Frequency & Percent & Cumulative Percent \\
\hline Business & 261 & 58.7 & 58.7 \\
\hline Private & 92 & 20.7 & 79.3 \\
\hline Public & 92 & 20.7 & 100 \\
\hline Total & 445 & 100 & \\
\hline
\end{tabular}

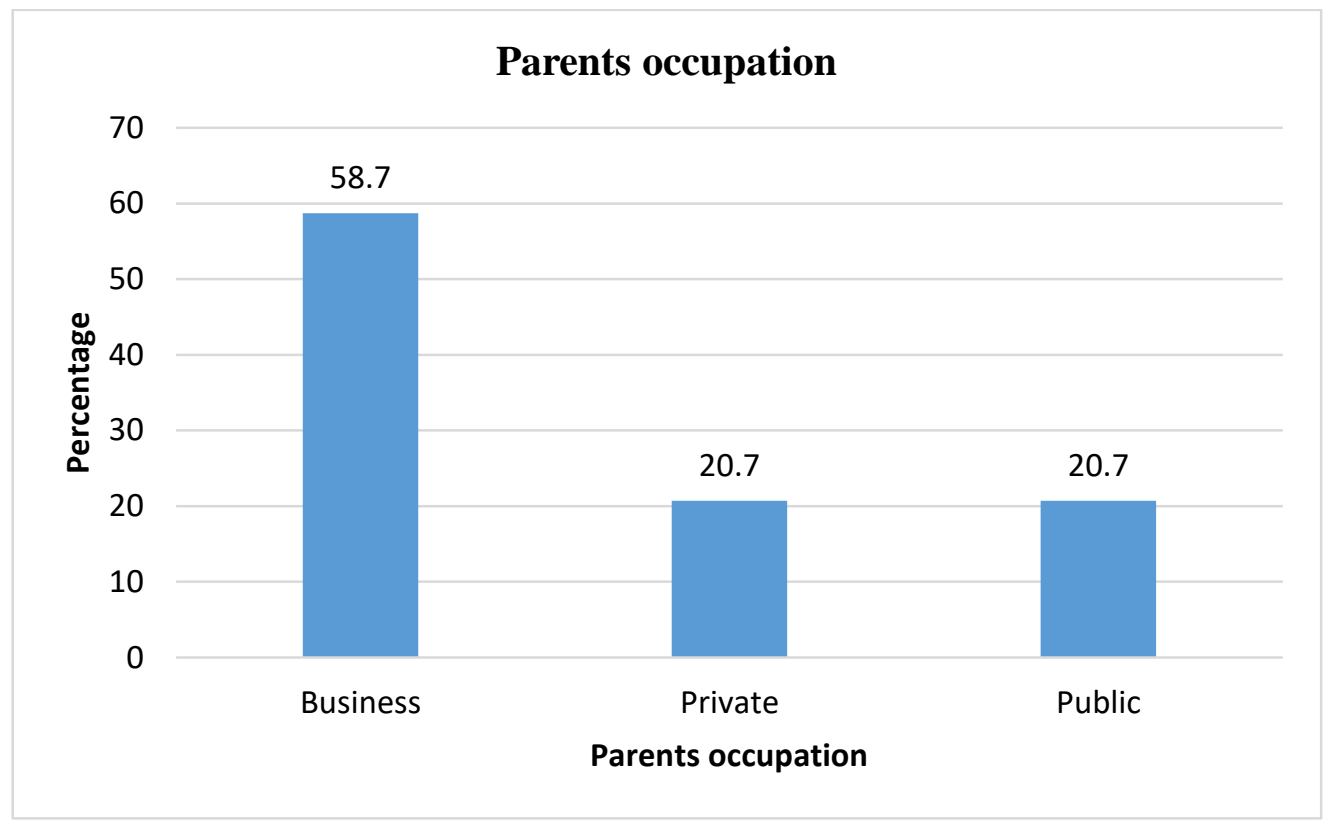

The study infers that majority of the respondents' parents were doing business and the rest was equally shared between their occupation associated with public and private organizations. The study has taken occupation as one of the demographic variables which might have a possible influence on the direct determinants of the study. In the table no:5.4, its saying that more than half of the sample belong to the business background. This might be interpreted in two ways. One, the student coming from a business background might have decided to take up Post Graduate course in business management to join the family business and develop it, secondly, students coming from business background might want a total shift in the career and move towards employment. The sample provides interesting opportunities to analyse the data in relation to the parental occupation and identifying the trends speculated above if any.

Parents annual income of the respondents

\begin{tabular}{|l|c|c|c|}
\hline \multicolumn{1}{|c|}{ Response types } & Frequency & Percent & Cumulative Percent \\
\hline 0-5 Lakhs & 214 & 48.1 & 48.1 \\
\hline 10 Lakhs and Above & 76 & 17.1 & 65.2 \\
\hline 5- 10 Lakhs & 155 & 34.8 & 100 \\
\hline Total & 445 & 100 & 100 \\
\hline
\end{tabular}




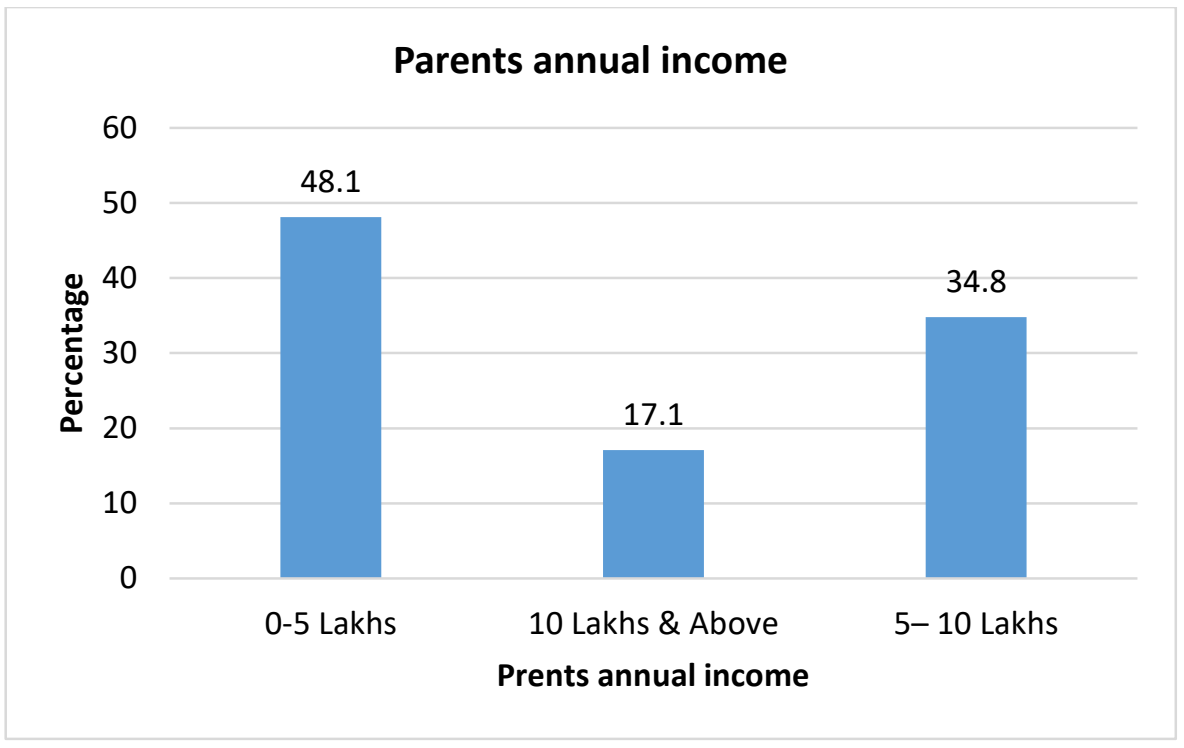

Parents annual income

The study infers that many of the management students' parents had an annual income between 0- 5 lakhs, and least come under the category of annual income between 5-10 lakhs. The income of the parents refers to the ability of the parents to support their children in search of employment and the necessity of the student to find employment at the earliest. The table above shows that majority of the parents $(48.1 \%)$ are in the income group of $0-5$ and therefore might require their wards to secure gainful employment at the end of their educational journey. This is also one of the reasons why educational institutions with good reputation and placement percentage are preferred by parents for their wards. This suggests the existence of relationship between income of the parents and the status of the institution which is an independent variable for the study. The study therefor can undertake further analysis of these dimensions to test the existence of relationship if any.

Table 4 Cross tabulation of Parent's occupation and UG

\begin{tabular}{|c|c|c|c|c|c|c|}
\hline \multicolumn{7}{|c|}{ Parent's occupation * UG } \\
\hline & & \multicolumn{4}{|c|}{$\mathbf{U G}$} & \multirow{2}{*}{ Total } \\
\hline & & Arts & BE & Others & Science & \\
\hline \multirow{3}{*}{ Parent's occupation } & Business & 158 & 82 & 5 & 16 & 261 \\
\hline & Private & 59 & 22 & 4 & 7 & 92 \\
\hline & Public & 62 & 25 & 0 & 5 & 92 \\
\hline \multicolumn{2}{|l|}{ Total } & 279 & 129 & 9 & 28 & 445 \\
\hline
\end{tabular}

From the study, it is inferred that majority of the respondents' parents who did business had their wards taking Arts as their Under Graduation followed by engineering as their second choice. It shows the parents support is also a deciding factor in determining the type of course their children should study. Choice of an UG course or study is often a decision made with active involvement of family members in a country like India. The table reveals that nearly 35.5 $\%$ of the total sample of respondents, have parents from Business community background. 
The finding is supported by Pepple (2014) [ 56], who identifies the impact of parental occupation on the students' choice of career is undeniable in a study conducted in Nigeria. Especially in a country like India, despite the existence of parental control and therefore the author argues that there is no relationship between parental influence and career views of students in science education. The impact of parental occupation is interpreted in terms of family support to the student leading to choice of career (fixing the agency) and the strength of desire to achieve it (pathway) is made using ANOVA in further analysis.

\section{Cross tabulation of Parent's occupation and PG CGPA}

\begin{tabular}{|c|c|c|c|c|c|}
\hline \multicolumn{5}{|c|}{ Parent's occupation * PG CGPA } \\
\hline & \multicolumn{3}{c|}{ Parent's occupation } & \multirow{2}{*}{ Total } \\
\cline { 3 - 6 } \multicolumn{2}{|c|}{} & Business & Private & Public & \\
\hline \multirow{4}{*}{ PG CGPA\% } & $9.1-10$ & 14 & 7 & 7 & 28 \\
\cline { 2 - 6 } & $8.1-9$ & 54 & 13 & 14 & 81 \\
\cline { 2 - 6 } & $7.1-8$ & 83 & 28 & 22 & 133 \\
\cline { 2 - 6 } & $6.1-7$ & 73 & 30 & 36 & 139 \\
\cline { 2 - 6 } & $5.1-6$ & 37 & 14 & 13 & 64 \\
\hline \multicolumn{2}{|c|}{ Total } & 261 & 92 & 92 & 445 \\
\hline
\end{tabular}

From the study, it is inferred that parents who did business had helped the students to secure good CGPA in their Post-Graduation when compared to the private and public sector. The study identifies better CGPA being scored by students whose parents come from business backgrounds. This may be interpreted in two ways: one, parents' business backgrounds may be providing better parental support to their wards leading to higher CGPA or the students with parents from business back grounds have the confidence of an assured fall-back job in terms of family business leading them to perform with higher confidence. It is seen that mostly, students with parents from business background have chosen Arts and Humanities related courses. The cross tabulation of parental occupation and CGPA presented in table 5.14 shows higher CGPA being secured by students with parents from business backgrounds. This may be interpreted in two ways: one, parents' business backgrounds may be providing better parental support to their wards leading to higher CGPA or the students with parents from business back grounds have the confidence of an assured fall-back job in terms of family business leading them to perform with higher confidence. These inferences suggest the possible existence of parental occupation on performance of the student which can be taken up for a further study in the future.

\section{Impact of family dimensions on employability}

H2: There is significant relationship between Emotional Intelligence and employability

H3: $\quad$ There is high possibility of perceived family support affecting employability

H4: $\quad$ There is significant relationship between parent personal involvement and employability 
Regression Summary

\begin{tabular}{|c|c|c|c|c|}
\hline \multicolumn{5}{|c|}{ Model Summary } \\
\hline Model & $\mathbf{R}$ & R Square & Adjusted R Square & $\begin{array}{c}\text { Std. Error of the } \\
\text { Estimate }\end{array}$ \\
\hline 1 & $.716^{\mathrm{a}}$ & .513 & .506 & 2.51855 \\
\hline
\end{tabular}

a. Predictors: Perceived family support, Parent Personal Involvement

b. Dependent Variable: Employability

The regression table indicate regression model fit for employability based on some independent variables.

$\mathbf{R}$ : represents the multiple correlation coefficients. The perceived $\mathrm{R}$ value is 0.716 , means that the dependent variable employability has a positive relationship with independent variables Status, Curriculum, Perceived family support, Parent Personal Involvement, Agency, pathway R square: represents the coefficient of determination. Since the $\mathrm{R}$ square value is 0.513 . It represents that $51.3 \%$ of the variance expressed by in dependent variable (Employability) on independent variables (Status, Curriculum, Perceived family support, Parent Personal Involvement, Agency, pathway)

Regression Summary

\begin{tabular}{|l|l|l|c|c|c|c|}
\hline \multicolumn{2}{|c|}{ ANOVA $^{\text {a }}$} \\
\hline \multicolumn{2}{|c|}{ Model } & $\begin{array}{c}\text { Sum of } \\
\text { Squares }\end{array}$ & Df & Mean Square & F & Sig. \\
\hline \multirow{2}{*}{1} & Regression & 2923.255 & 6 & 487.209 & 76.809 & $<0.001^{* *}$ \\
\cline { 2 - 8 } & Residual & 2778.278 & 438 & 6.343 & & \\
\cline { 2 - 8 } & Total & 5701.533 & 444 & & & \\
\hline
\end{tabular}

a. Dependent Variable: Employability

Predictors: (Perceived family support, Parent Personal Involvement

** denotes significant at $1 \%$ level

In the above table, ANOVA result 'p' value is significant (Which is less than 0.05) reflect that dependent variable employability is more reliable.

Regression Table Summary

\begin{tabular}{|c|c|c|c|c|c|}
\hline \multicolumn{6}{|c|}{ Coefficients $^{\mathbf{a}}$} \\
\hline \multirow[t]{2}{*}{ Model } & \multicolumn{2}{|c|}{$\begin{array}{c}\text { Unstandardized } \\
\text { Coefficients }\end{array}$} & \multirow{2}{*}{$\begin{array}{c}\text { Standardized } \\
\text { Coefficients }\end{array}$} & \multirow[t]{2}{*}{$\mathbf{t}$} & \multirow[t]{2}{*}{ Sig. } \\
\hline & $\mathbf{B}$ & Std. Error & & & \\
\hline Perceived family support & 1.315 & \begin{tabular}{l|l}
.092 \\
\end{tabular} & .562 & 14.308 & $<0.001 * *$ \\
\hline Parent Personal Involvement & 1.472 & .094 & .596 & 15.621 & $<0.001 * *$ \\
\hline
\end{tabular}

The above coefficient table values indicate that the, independent variables of Perceived family support and Parent Personal Involvement are indicating very strong significant impact with dependent variable employability. 


\begin{tabular}{|c|l|c|}
\hline Hypothesis & \multicolumn{1}{|c|}{$\begin{array}{c}\text { Hypothesis testing for dependent and } \\
\text { independent variable }\end{array}$} & $\begin{array}{c}\text { Accept/ } \\
\text { Reject }\end{array}$ \\
\hline $\mathrm{H} 2$ & $\begin{array}{l}\text { There is significant relationship between } \\
\text { Emotional Intelligence and employability }\end{array}$ & Accepted \\
\hline $\mathrm{H} 3$ & $\begin{array}{l}\text { There is high possibility of perceived family } \\
\text { support affecting employability }\end{array}$ & Accepted \\
\hline $\mathrm{H} 4$ & $\begin{array}{l}\text { There is significant relationship between } \\
\text { parent personal involvement and } \\
\text { employability }\end{array}$ & Accepted \\
\hline
\end{tabular}

O'Donnell (2014) identifies the existence of relationship between parental expectations and student performance with relation school children. Most of the studies conducted are in relation to impact of parental involvement on school children. This identifies the need to undertake a further study in the area of students of higher education. The researcher who is an incumbent of higher educational institution has often witnessed the students coming for post graduate admissions with theparents in tow. Therefore, in the Indian family structure and social system, parental involvement is found not only at the school level but may extend to higher education also. This aspect makes further study for validation. With reference to family expectations and its impact on the student achievement sometimes there is a possibility for a student to feel the stress created out of parental expectations. An examination of this dimension with reference to the Indian environment may prove to be beneficial.

\section{Moderating effect of EI on family dimensions and employability}

H5: There is significant moderator effect of EI between Perceived Family Support and employability

H 6: There is positive moderating influence of EI on the relationship between Parent Personal Involvement and employability

The PROCESS macro for SPSS by Hayes (2012) [57] has used in this research to run the bootstrapping model and estimate the mediation effect. This macro package estimates the unstandardized path co-efficient value (Beta) of a mediation model by assessing the four mediation steps [58].

\section{Results of Process Macro}

\begin{tabular}{|l|c|c|c|c|c|}
\hline \multicolumn{1}{|c|}{ Relationship } & $\begin{array}{c}\text { Unstandardized } \\
\text { Coefficients } \\
\text { B }\end{array}$ & $\begin{array}{c}\text { Unstandardized } \\
\text { Coefficients } \\
\text { SE }\end{array}$ & T value & P value & $\begin{array}{c}\text { Study } \\
\text { Results }\end{array}$ \\
\hline $\begin{array}{l}\text { Emotional } \\
\text { Intelligence } \\
\rightarrow \text { Employability }\end{array}$ & 0.883 & 0.063 & 39.526 & $<0.001^{* *}$ & Significant \\
\hline
\end{tabular}




\begin{tabular}{|l|l|l|l|l|l|}
\hline $\begin{array}{l}\text { Family support } \rightarrow \\
\text { Employability }\end{array}$ & 1.315 & 0.092 & 14.308 & $<0.001^{* *}$ & Significant \\
\hline $\begin{array}{l}\text { Perceived Parental } \\
\text { Involvement } \rightarrow \\
\text { Employability }\end{array}$ & 1.472 & 0.094 & 15.621 & $<0.001^{* *}$ & Significant \\
\hline $\begin{array}{l}\text { Emotional } \\
\text { Intelligence } * \\
\text { Family support } \\
\rightarrow\end{array}$ & 0.0439 & 0.0341 & 1.284 & 0.1996 & $\begin{array}{l}\text { Not } \\
\text { Employabificant }\end{array}$ \\
\hline $\begin{array}{l}\text { Emotional } \\
\text { Intelligence } * \\
\text { Parents personal } \\
\text { involvement } \\
\text { Employability }\end{array}$ & 0.0420 & 0.0341 & 1.2291 & 0.2197 & $\begin{array}{l}\text { Not } \\
\text { Significant }\end{array}$ \\
\hline
\end{tabular}

Note: $1 . * *$ denotes significant at $1 \%$ level

2. * denotes significant at $5 \%$ level

\section{Inference:}

The above table shows that the direct relationship, emotional intelligence and employability has the positive and significant effect (39.526). Perceived family support has significant impact on employability (14.308). Parent Personal Involvement also has significant impact on employability (15.621).

The moderating impact of Emotional Intelligence and Employability is interpreted from the calculated table and found that there is no moderating impact of Emotional intelligence on the relationship between Perceived family support and Employability (1.284) and Parent Personal Involvement and Employability (1.2291).

O'Donnell (2014) identifies the existence of relationship between parental expectations and student performance with relation school children. Most of the studies conducted are in relation to impact of parental involvement on school children. This identifies the need to undertake a further study in the area of students of higher education. The researcher who is an incumbent of higher educational institution has often witnessed the students coming for post graduate admissions with the parents in tow. Therefore, in the Indian family structure and social system, parental involvement is found not only at the school level but may extend to higher education also. This aspect makes further study for validation.

\section{CONCLUSION}

The present study proves the existence of impact of EI as a moderator on the relationship between the family dimensions and employability. It proved that there is direct 
impact of family dimension on employability but there is negative moderating role of Emotional Intelligence on the same relationship. The interaction might be quiet complex and will require a comprehensive enquiry. This will also help the family members to understand the sort of support and involvement they can show the students to get their employment. In a country like India where family has a very important role in each and every social and academic engagement of the students, Institutions can also educate parents to provide necessary emotional support to the students. A preliminary attempt was made in the present study to understand the impact of community on employability but a future study in the area of community and employability of experienced employees can be undertaken to understand the full significance of community and its impact on employability. In the Indian family structure and social system, parental involvement is found not only at the school level but may extend to higher education also. This aspect makes further study for validation. With reference to family expectations and its impact on the student achievement sometimes there is a possibility for a student to feel the stress created out of parental expectations. An examination of this dimension with reference to the Indian environment may prove to be beneficial.

\section{References:}

[1] Harvey, L., (2001), "Defining and measuring employability. Quality in Higher Education”, 7(2), pp. 97-109

[2] [21] Opengart, R., and Short, D., (2002), "Free agent learners: The new career model and its impacton human resource development", International Journal of Lifelong Education, 22(1), pp 220-233

[3] [22] Butterwick, Shauna and Benjamin, Amanda., (2006), "The road to employability through personal development: A critical analysis of the silences and ambiguities of the British Columbia (Canada) Life Skills Curriculum", International Journal of Lifelong Education, (25. 10.1080/02601370500309543)

[4] McMahon, M., Patton, W., and Tatham, P., (2003), "Managing life, learning and work in the twenty-first century: Issues informing the design of an Australian Blueprint for Career Development", (Retrieved February 9, 2005, from http://www.lifework.ca/AUSBP04-03.pdf)

[5] Brown, Phillip and Hesketh, Anthony., (2005), "The Mismanagement of Talent: Employability and Jobs in the Knowledge Economy", Industrial and Labor Relations Review, 50, (10.2189/asqu.2005.50.2.306)

[6] Yorke, Mantz., (2006), "Employability in Higher Education: What It Is, What It Is Not"

[7] Hillage, Jim and Pollard, Emma., (1998), "Employability: Developing a framework for policy analysis. Labour Market Trends", 107, pp. 83-84

[8] Harvey, L., (2002), "Employability and Diversity", (http://www2. wlv.ac.uk/ webteam/confs/socdiv/ sdd-harvey -0602.doc)

[9] Opengart, R., and Short, D., (2002), "Free agent learners: The new career model and its impacton human resource development", International Journal of Lifelong Education, 22(1), pp 220-233

[10] Butterwick, Shauna and Benjamin, Amanda., (2006), "The road to employability through personal development: A critical analysis of the silences and ambiguities of the 
British Columbia (Canada) Life Skills Curriculum", International Journal of Lifelong Education, (25. 10.1080/02601370500309543)

[11] McMahon, M., Patton, W., and Tatham, P., (2003), "Managing life, learning and work in the twenty-first century: Issues informing the design of an Australian Blueprint for Career Development", (Retrieved February 9, 2005, from http://www.lifework.ca/AUSBP04-03.pdf)

[12] Henry, Colette and Hill, Frances and Leitch, Claire., (2005), "Entrepreneurship Education and Training: Can Entrepreneurship Be Taught? Part II. Education + Training", 47, pp. 98-111 (10.1108/ 004009 10510586524)

[13] Wickramasinghe, Vathsala and Perera, Lasantha. (2010). "Graduates', university lecturers' and employers' perceptions towards employability skills”. Education + Training. 52. 226-244. 10.1108/00400911011037355.

[14] Atkins, M. J., (1999), "Oven-ready and self-basting: Taking stock of employability skills", Teaching in Higher Education, 4(2), pp.267-280

[15] Billing, D., (2003), "Generic cognitive abilities in higher education: An international analysis of skills sought by stakeholders", Compare, 33(3), pp.335-350

[16] Elias, P., and Purcell, K., (2004), "Is Mass Higher Education Working? Evidence from the Labour Market Experience of Recent Graduates", National Institute Economic Review 190(1), pp 60-74, (doi:10.1177/ 002795010419000107 )

[17] Allen, Kelly-Ann. (2010), "Book Review: Peter Jarvis, Learning to be a Person in Society”, London: Routledge, Educational Psychology, 30, pp 244-245

[18] Brown, R. P., (2003), "Measuring individual differences in the ten-dency to forgive: Construct validity and links with depression", Personality and Social Psychology Bulletin, 29, pp 759-771

[19] Duchesne, Stéphane and Ratelle, Catherine. (2010). "Parental Behaviors and Adolescents' Achievement Goals at the Beginning of Middle School: Emotional Problems as Potential Mediators”. Journal of Educational Psychology. 102. 497-507. $10.1037 / \mathrm{a} 0019320$.

[20] Hirudayaraj (2011), "First-Generation Students In Higher Education: Issues Of Employability in A Knowledge Based Economy", Online Journal for Workforce Education and Development, Volume V, Issue 3

[21] Wanberg, Connie. (2010). "The Individual Experience of Unemployment. Annual review of psychology”. 63. 369-96. 10.1146/annurev-psych-120710- 100500.

[22] Rice, K. G., Cunningham, T. J., and Young, M. B. (1997). "Attachment to parents, social competence, and emotional well-being: A comparison of Black and White late adolescents". Journal of Counseling Psychology, 44(1), 89- 101. https://doi.org/10.1037/0022-0167.44.1.89

[23] Fincham, R. and Clark, T. 2006. Within and beyond communities of practice: "Making sense of learning through participation, identity and practice". Journal of Management Studies,43(3):641-653.

[24] Whiston and Keller(2004), "The Influences of the Family of Origin on Career development: A Review and Analysis", The counselling psychologist, https://doi.org/10.1177/0011000004265660

[25] Yoko Yamamoto and Susan D. Holloway, "Parental Expectations and Children's 
Academic Performance in Sociocultural Context," Educational Psychological Review 22 (2010): 189-214.

[26] Metheny, J., and McWhirter, E. H. (2013). "Contributions of social status and family support to college students" career decision self-efficacy and outcome expectations. Journal of Career Assessment, 21(3), 378-394. https://doi.org/10.1177/1069072712475164

[27] Smits, J. and A. G. Hosgor. 2006. Effects of family background characteristics on educational participation in Turkey. International Journal of Educational Development 26: 545-560.

[28] S. Sasikala and S. Karunanidhi(2011),Development and Validation of Perception of Parental Expectations' Inventory, An Analysis of IndividualismCollectivism across Northern India, JIAAP, ISSN 0019- 4247

[29] .Sriram R, Sandhu GK. Fathering to Ensure Child's Success: What Urban Indian Fathers Do? Journal of Family Issues. 2013;34(2):159-181. doi:10.1177/0192513X12461136

[30] Vellymalay (2011), A study of the relationship between Indian parents' education level and their involvement in their children's education, Penerbit Universiti Sains Malaysia, 2011

[31] Thergaonkar (2007), Relationship between Test Anxiety and Parenting Style, J. Indian Assoc. Child Adolesc. Ment. Health 2007; 2(4): 10-12

[32] Hossain, M. Shahadat and Chowdhury, Sayedur and Das, Nani and Sharifuzzaman, Sm and Sultana, Abida. (2009). "Integration of GIS and multicriteria decision analysis for urban aquaculture development in Bangladesh. Landscape and Urban Planning”. 90. 119-133. 10.1016 /j.landurbplan.2008.10.020.

[33] Aziz, Atif and Raza, Muhammad and Al-Deehani, Talla. (2020). "The role of emotional intelligence and perceived employability in undergraduate's student."

[34] Coetzee, M., and Schreuder, D. (2011). "The relation between career anchors , emotional intelligence and employability satisfaction among workers in the service industry." Southern African Business Review, 15(3), 76-97.

[35] Boyatzis, Richard. (2007). "Developing emotional intelligence competencies. Applying Emotional Intelligence: A Practitioner's Guide". 28-52.

[36] Boyatzis, Richard. (2006). "An overview of intentional change from a complexity perspective". Journal of Management Development. 25. 607-623. 10.1108/02621710610678445.

[37] Bezuidenhout, Adele and Cilliers, Frans. (2010).” Burnout, work engagement and sense of coherence in female academics in higher-education institutions in South Africa". SA Journal of Industrial Psychology. 36. 1-10. 10.4102/sajip.v36i1.872.

[38] Goleman, D. (1998), 'Working with Emotional Intelligence”, Bantam Dell, New York, NY.

[39] Dacre Pool, Lorraine and Qualter, Pamela. (2013). "Emotional self-efficacy, graduate employability, and career satisfaction: Testing the associations. Australian Journal of Psychology”. 65. 10.1111/ajpy.12023.

[40] Evers, F. T., Rush, J. C., and Berdrow, I., (1998), “The bases of competence. Skills for lifelong learning and employability. San Francisco: Jossey-Bass" 
[41] Mandava Neelima (2011), "A study of self-confidence and mental health in relation to emotional intelligence of college students", Thesis, Acharya Nagarjuna University

[42] Bai, H. (2011). "Emotional Intelligence Meets Virtue Ethics: Implications for Educators". Journal of Thought, 46(3-4), 25-43. doi:10.2307/ jthought. 46.3- 4.25

[43] Hasanzadeh, Ramezan and Shahmohamadi, Fatema. (2011). "Study of Emotional Intelligence and Learning Strategies". Procedia - Social and Behavioral Sciences. 29. 10.1016/j.sbspro.2011.11.430.

[44] Meysam Zafari, Reza Biria," The Relationship between Emotional Intelligence and Language Learning Strategy "Use, Procedia - Social and Behavioral Sciences, Volume 98, 2014, Pages 1966-1974, ISSN 1877-0428, https://doi.org/10.1016/j.sbspro.2014.03.630

[45] Puffer, (2010) "Emotional Intelligence as a Salient Predictor for Collegians" Career Decision Making, vol 19, https://doi.org/10.1177/ 1069072710385545.

[46] Coetzee, Melinde and Schreuder, Dries and Tladinyane, Rebecca. (2014). "Employees' work engagement and job commitment: The moderating role of career anchors." SA Journal of Human Resource Management. 12. 10.4102/sajhrm. v12i1.572.

[47] Rateau, R. J., Broyles, T. W., Fowler, S. B., and Robinson, J. S. (2011). "Understanding the Employability of College Graduates for Success in the Workplace" (Doctoral dissertation, Virginia Tech).

[48] Ahangar, Reza. (2012). "Emotional Intelligence: The Most Potent Factor of Job Performance Among Executives". 10.5772/32337.

[49] Agata et al (2012) "Why are people high in emotional intelligence happier? They make the most of their positive emotions. Personality and Individual Differences." 117. 177181. 10.1016/j.paid.2017.05.051.

[50] Fabio, Annamaria and Palazzeschi, Letizia and Bucci, Ornella. (2017)." Gratitude in Organizations: A Contribution for Healthy Organizational Contexts". Frontiers in Psychology. 8. 10.3389/fpsyg.2017.02025.

[51] Gift Rupande, "The Impact of Emotional Intelligence on Student Learning" International Journal of Managerial Studies and Research 2015 , 3(9) : 133-136

[52] Waheed Hussain (2009), "The most stable just regime, Journal of social philosophy", vol 40, No.3, Fall 2009, 412- 433, Wiley periodicals Inc.

[53] Baron, R. M., and Kenny, D. A. (1986). "The moderator-mediator variable distinction in social psychological research: Conceptual, strategic, and statistical considerations. Journal of Personality and Social Psychology," 51(6), 1173-1182

[54] Sewell, P., and Pool, L. D. (2010). "Moving from conceptual ambiguity to operational clarity." Education+ Training.

[55] Petrides, K. V. (2009). Psychometric properties of the Trait Emotional Intelligence Questionnaire. In C. Stough, D. H. Saklofske, and J. D. Parker, Advances in the assessment of emotional intelligence. New York: Springer. DOI: 10.1007/978-0-38788370-0_5

[56] Pepple (2014), 'You have to be well spoken': students' views on employability within the graduate labour market". Journal of Education and Work, 1-20. 